\title{
The Influence of Fertilizers on Cigar-Filler Tobacco Quality
}

\author{
George Samuels \\ INTRODUCTION
}

Cigar-filler tobacco is a quality crop. That is to say, the farmer is paid not only for how many pounds of tobacco he can produce per acre, but also for the grade of quality of the tobacco he produces. The prices paid for cured tobacco vary from 44 cents for highest quality, Class I, to 13 for lowest quality, Class VI ${ }^{2}$. With such a wide price range, it makes it well worthwhile for the farmer to try to obtain as high a quality as possible in his tobacco harvest.

The tobacco farmer is extremely interested in any factor which can favorably influence the quality grading of his tobacco. We know that soils, weather, variety, time and method of harvesting, and fertilizers can influence tobacco quality. Unfortunately, the farmer has little control over some of these factors. However, one which he can control is the fertilizing of his tobacco. He thus becomes concerned with the following questions: Does too much fertilizer give high tobacco yields, but poor quality? Can certain fertilizer elements help increase the quality of the tobacco crop even if it will not be of value in increasing yields of tobacco?

It is the purpose of this paper to answer these and other questions concerned with the influence of fertilizers on the quality of cigar-filler tobacco in Puerto Rico.

\section{PROCEDURES}

The data for this study were taken from the fertilizer experiments on tobacco reported in a previous publication $(5)^{3}$. Three crops of the Aibonito experiment on a Juncos clay were selected for the influence of major-element fertilizers $\left(\mathrm{N}-\mathrm{P}_{2} \mathrm{O}_{5}-\mathrm{K}_{2} \mathrm{O}\right)$ on tobacco quality and one crop of the Caguas experiment on a Caguas clay was selected for the influence of various nitrogen-fertilizer sources on tobacco quality.

In all experiments, the dried leaves were classified, using the standard

${ }^{1}$ Agronomist, Agricultural Experiment Station, University of P. R., Río Piedras, P. R. The author wishes to thank P. Landrau, Jr., S. Alers-Alers, and C. González Molina, who did the original field work; F. González-Vélez for help in the price calculations; M. Manzano for his work in the nicotine analyses, and A. Amy for his advice on tobacco prices and grading.

2 Prices based on 1958 loan rate of farm delivery weight of cured tobacco.

${ }^{3}$ Italic numbers in parentheses refer to Literature Cited, pp. 206-7. 
grades for Puerto Rican cigar-leaf tobacco (U.S. Type 46), as designated by the Tobacco Division, Agricultural Marketing Service, U.S. Department of Agriculture. The classified air-cured tobacco was then weighed. The cash value of each treatment was calculated from the sum of the products of the yield of each standard grade and the price per pound of each grade. The relationship between the standard grade and its price class is given in table

TABLE 1.-Classification of cured cigar-filler tobacco (U.S.

Type 46) and prices (cents) for various grades, 1951-58

\begin{tabular}{|c|c|c|c|c|}
\hline $\begin{array}{l}\text { U.S. } \\
\text { Grade }\end{array}$ & Grade description & Equivalent grade in Spanish & Class & $\begin{array}{l}\text { Price } \\
\text { per } \\
\text { pound }\end{array}$ \\
\hline CIF & $\begin{array}{l}\text { Choice medium-bodied } \\
\text { stripper }\end{array}$ & Medio fino & I & 44 \\
\hline CIP & Choice heavy stripper & Calidad mediana & $\mathbf{I}$ & 44 \\
\hline CIM & Choice and fine stripper & Manojo 1 y 2 & $\mathbf{I}$ & 44 \\
\hline $\mathrm{C} 2 \mathrm{~F}$ & Fine thin stripper & Pie superior & $\mathbf{I}$ & 44 \\
\hline $\mathrm{C} 2 \mathrm{P}$ & Fine heavy stripper & Corona larga & I & 44 \\
\hline C3F & Good thin stripper & Pie & II & 36 \\
\hline C3P & Good heavy stripper & Corona corta & II & 36 \\
\hline C3M & do. & Manojo 3 & II & 36 \\
\hline C3T & Good thin stripper & Tripa & II & 36 \\
\hline C3S & Slightly stained & Supcrior ligeramente manchado & II & 36 \\
\hline XIF & Choice thin filler & Pie inferior o regazo fino & III & 25 \\
\hline XIP & Choice heavy filler & Corona inferior o regazo calidad & III & 25 \\
\hline $\mathrm{X} 2 \mathrm{~F}$ & Good thin filler & Boliche fino superior & IV & 20 \\
\hline $\mathrm{X} 2 \mathrm{P}$ & Good heavy filler & Boliche calidad superior & IV & 20 \\
\hline X2PT & Good heavy short filler & Boliche calidad corto & V & 16 \\
\hline $\mathrm{X} 3 \mathrm{~F}$ & $\begin{array}{l}\text { Materially injured thin } \\
\text { filler }\end{array}$ & Defectuoso fino & V & 16 \\
\hline X3P & $\begin{array}{l}\text { Materially injured heavy } \\
\text { filler }\end{array}$ & Defectuoso pesado & V & 16 \\
\hline X3S & Stained filler & Manchado & V & 16 \\
\hline $\mathrm{X} 4$ & Badly injured filler & Defectuoso inferior verde & VI & 12 \\
\hline YI & Trashy filler & Rabia & VI & 12 \\
\hline
\end{tabular}

1. Also calculated was the average price received per pound of tobacco for the various treatments. This was calculated by dividing the cash value per acre of the cured tobacco by the total pound-yield per acre of tobacco produced.

From the Caguas experiment the weighed and cured tobacco was fermented and then cigars were made from that grown under the various fertilizer treatments. The cigars were smoked in a smoking machine designed ${ }^{4}$

1 The smoking machine was designed and used by M. Manzano, Assistant Biochemist at this Station. 
to imitate the intermittent smoking of human smokers. With the help of a water syphon, suction was applied to the cigars for a period of 8 seconds, followed by a pause of 20 seconds while the syphon was filling up again for the next draw. The weight of tobacco burned in a period of 30 minutes was recorded. The color of the ash produced was evaluated by comparison to an arbitrary scale of colors by which 1 designated pure-white ash and 12 black cigar ash. For each treatment, 18 cigars were utilized-3 each of the 6 replications.

Nicotine analyses were made from the fermented tobacco of the first crop of the Aibonito experiment. Total nicotine was determined by the Keller method (4). The free nicotine in the tobacco was determined by the $\mathrm{pH}$ method (1).

\section{RESULTS}

\section{MAJOR-ELEMENT FERTILIZERS}

\section{Nitrogen}

There was a definite increase in the quality of the tobacco produced when nitrogen fertilizer was used. The use of 50 pounds per acre of nitrogen gave an increase of $\$ 290$ per acre as compared to no-nitrogen fertilizer being applied (see table 2). Of course, this would be expected, inasmuch as the 50pound-per-acre nitrogen treatment had increased yields of cured tobacco almost 6 hundredweights per acre. However, as seen in the last column of table 2, the price of the tobacco increased from 30 to 38 cents per pound. This indicates that the applied nitrogen improved the quality of the tobacco so that tobacco produced by the 50 pound-nitrogen-per-acre treatment averaged 8 cents more per pound because of higher classification grades than did the tobacco receiving no nitrogen. Checking back into the various classification grades, it was found that under the no-nitrogen treatment, 75 percent of the tobacco classified in the highest price classification and 10 percent in the lowest; whereas, when 50 pounds of nitrogen per acre were used, 82 percent was in the highest classification and only 4 percent in the lowest.

Further nitrogen applications, above 50 pounds per acre, did not cause significant increases in yields of tobacco nor in price paid per acre or pound. Although price increases per pound of tobacco grown were not significant, it is interesting to note that increasing nitrogen applications up to 150 pounds per acre did not decrease the quality of the tobacco. It should be remembered that these increasing nitrogen applications were all accompanied by ample applications of phosphate and potash fertilizers. 
TABLE 2.-The influence of fertilizers and soil amendments on the yield and price of cured tobacco, Aibonito experiments, mean of $\$$ crops, 1951-54

\begin{tabular}{|c|c|c|c|c|c|}
\hline \multicolumn{3}{|c|}{ Fertilizer treatments in pounds per acre of- } & \multirow{2}{*}{$\begin{array}{l}\text { Yield of cured } \\
\text { tobacco per acre }\end{array}$} & \multirow{2}{*}{$\begin{array}{l}\text { Price of cured } \\
\text { tobacco per acre }\end{array}$} & \multirow{2}{*}{$\begin{array}{l}\text { Price of cured } \\
\text { tobacco per } \\
\text { pound }\end{array}$} \\
\hline $\mathbf{N}$ & $\mathrm{P}_{2} \mathrm{O}_{3}$ & $\mathrm{~K}_{2} \mathrm{O}$ & & & \\
\hline \multicolumn{6}{|c|}{ Nitrogen $(N)$} \\
\hline $\begin{array}{r}0 \\
50 \\
100 \\
150\end{array}$ & $\begin{array}{l}100 \\
100 \\
100 \\
100\end{array}$ & $\begin{array}{l}150 \\
150 \\
150 \\
150\end{array}$ & $\begin{array}{c}\text { Cwt. } \\
7.79 \\
13.66 \\
14.49 \\
14.71\end{array}$ & $\begin{array}{c}\text { Dollars } \\
229.81 \\
519.08 \\
584.61 \\
603.11\end{array}$ & $\begin{array}{c}\text { Cents } \\
30 \\
38 \\
39 \\
41\end{array}$ \\
\hline \multicolumn{6}{|c|}{ Phosphorus $\left(\mathrm{P}_{2} \mathrm{O}_{6}\right)$} \\
\hline $\begin{array}{l}150 \\
150 \\
150\end{array}$ & $\begin{array}{r}0 \\
50 \\
100\end{array}$ & $\begin{array}{l}150 \\
150 \\
150\end{array}$ & $\begin{array}{l}10.97 \\
13.91 \\
14.71\end{array}$ & $\begin{array}{l}427.83 \\
542.49 \\
603.11\end{array}$ & $\begin{array}{l}39 \\
39 \\
41\end{array}$ \\
\hline \multicolumn{6}{|c|}{ Potassium $\left(\mathrm{K}_{2} \mathrm{O}\right)$} \\
\hline $\begin{array}{l}150 \\
150 \\
150 \\
150\end{array}$ & $\begin{array}{l}100 \\
100 \\
100 \\
100\end{array}$ & $\begin{array}{r}0 \\
50 \\
100 \\
150\end{array}$ & $\begin{array}{l}13.68 \\
14.62 \\
14.61 \\
14.71\end{array}$ & $\begin{array}{l}547.20 \\
599.42 \\
569.79 \\
603.11\end{array}$ & $\begin{array}{l}40 \\
41 \\
39 \\
41\end{array}$ \\
\hline \multicolumn{6}{|c|}{ Soil amendments } \\
\hline $\begin{array}{l}100 \\
100\end{array}$ & $\begin{array}{l}100 \\
100\end{array}$ & $\begin{array}{l}150 \\
150\end{array}$ & 14.49 & 584.61 & 39 \\
\hline \multicolumn{3}{|c|}{ plus $1,000 \mathrm{lb}$ of lime } & 16.67 & 733.48 & 44 \\
\hline \multicolumn{3}{|c|}{ plus $2,000 \mathrm{lb}$. of lime } & 16.22 & 697.46 & 43 \\
\hline 100 & 100 & 150 & & & \\
\hline \multicolumn{3}{|c|}{ plus $300 \mathrm{lb}$. of magnesium oxide } & 14.25 & 612.75 & 43 \\
\hline
\end{tabular}

Least significant differences needed between treatments:

\begin{tabular}{l|l|r|r} 
5-percent level & 2.40 & 91.14 & 3.8 \\
1-percent level & 3.12 & 120.90 & 5.0 \\
\hline
\end{tabular}

\section{Phosphorus}

Increases in the price of cured tobacco per acre was obtained with the use of 50 pounds of $\mathrm{P}_{2} \mathrm{O}_{5}$ per acre (table 2). This was in keeping with the increase in yield of tobacco per acre also obtained with the use of the 50 
pounds of $\mathrm{P}_{2} \mathrm{O}_{5}$ per acre. However, no increase in the price of cured tobacco per pound was obtained, which indicated that phosphate fertilizers increased yields of tobacco, which, in turn, gave more money per acre to the farmer, but tobacco quality was not influenced significantly by their use.

No further significant increases in yields or price per acre or per pound of tobacco were realized when 100 pounds instead of 50 of $\mathrm{P}_{2} \mathrm{O}_{5}$ per acre were used.

\section{Potassium}

Neither yields of cured tobacco nor price per acre or pound were significantly increased by using potash fertilizers on the three experiments at Aibonito on a Juncos clay. For Puerto Rico, the tobacco fertilizers used have relatively high potash analyses. The two grades approved for use with tobacco are a 6-8-10 or 8-6-10. Higher quantities of potash in relation to nitrogen or phosphates have been justified locally on the assumption of need of potash to produce "better quality". It appears that, at least for the Juncos clay, ample potash is present in the soil to give both good yield and quality. The use of rates of up to 150 pounds of $\mathrm{K}_{2} \mathrm{O}$ per acre did not increase the quality of the tobacco. With no potash the average price per pound was 40 cents and with 150 pounds of $K_{2} \mathrm{O}$ per acre it was 41 cents (see table 2).

\section{SOIL AMENDMENTS}

The use of 1,000 pounds of limestone almost produced significant increases in yields of cured tobacco per acre (table 2). It, in turn, gave significant increases in the price received per acre for this tobacco as compared to no liming. But this increase in money received was due not only to the increased yields, because the quality of the tobacco also increased with the use of lime. The unlimed tobacco averaged 39 cents per pound, whereas lime increased this to 44 cents per pound-an average increase of 5 cents per pound of cured tobacco because of liming. The use of 2,000 pounds of limestone instead of 1,000 did not increase quality any further.

Magnesium oxide did not increase yields of tobacco significantly, but it did increase its quality. The use of 300 pounds of magnesium oxide per acre increased the price per pound of the cured tobacco from 39 to 43 cents.

\section{SOURCES OF NITROGEN}

The source of nitrogen used did not appreciably influence the quality of the tobacco as reflected in its price per pound, which varied from 39 to 43 cents (table 3). Ammonium sulfate, the accepted nitrogen source in use in Puerto Rico, was among the nitrogen sources which gave the highest yields per acre as well as the best price per pound of tobacco. Such nitrogen sources as calcium cyanamide, urea, and filter-press cake gave poor yields, 
but quality as reflected in price paid per pound was not lowered significantly.

TABLE 3.-The influence of source of nitrogen on the yield and price of cured tobacco per acre, Caguas experiment, 1954

\begin{tabular}{|c|c|c|c|c|}
\hline Sources of nitrogen & $\begin{array}{l}\text { Nitrogen } \\
\text { content }\end{array}$ & $\begin{array}{c}\text { Yield of cured } \\
\text { tobacco per } \\
\text { acre }\end{array}$ & $\begin{array}{l}\text { Price of cured } \\
\text { tobacco } \\
\text { per acre }\end{array}$ & $\begin{array}{c}\text { Price of } \\
\text { cured } \\
\text { tobacco per } \\
\text { pound }\end{array}$ \\
\hline \multicolumn{5}{|c|}{ Inorganic } \\
\hline $\begin{array}{l}\text { Ammonium sulfate } \\
\text { Ammonium nitrate } \\
\text { Ammonium sulfate nitrate } \\
\text { Calcium ammonium nitrate } \\
\text { Calcium cyanamide } \\
\text { Calcium nitrate } \\
\text { Potassium nitrate } \\
\text { Sodium nitrate } \\
\text { Urea }\end{array}$ & $\begin{array}{c}\text { Percent } \\
20 \\
33 \\
25 \\
20 \\
18 \\
15 \\
14 \\
16 \\
46\end{array}$ & $\begin{array}{r}\text { Cwt. } \\
12.54 \\
11.82 \\
12.48 \\
11.42 \\
5.16 \\
11.78 \\
11.34 \\
11.37 \\
8.62\end{array}$ & $\begin{array}{c}\text { Dollors } \\
541.18 \\
500.86 \\
542.08 \\
486.53 \\
218.62 \\
503.55 \\
467.71 \\
488.32 \\
350.03\end{array}$ & $\begin{array}{l}\text { Cenis } \\
43 \\
42 \\
43 \\
43 \\
42 \\
43 \\
41 \\
43 \\
41\end{array}$ \\
\hline \multicolumn{5}{|c|}{ Organic } \\
\hline $\begin{array}{l}\text { Castor pomace } \\
\text { Cottonseed meal } \\
\text { Filter-press cake }\end{array}$ & $\begin{array}{l}5 \\
7 \\
2\end{array}$ & $\begin{array}{l}11.40 \\
12.29 \\
10.45\end{array}$ & $\begin{array}{l}482.05 \\
522.37 \\
411.26\end{array}$ & $\begin{array}{l}42 \\
43 \\
39\end{array}$ \\
\hline \multicolumn{5}{|c|}{ Mixtures } \\
\hline $\begin{array}{l}1 / 2 \text { ammonium sulfate plus } 1 / 2 \text { cottonseed } \\
\text { meal } \\
1 / 2 \text { urea plus } 1 / 2 \text { cottonseed meal } \\
1 / 3 \text { urea plus } 1 / 3 \text { ammonium sulfate plus } \\
1 / 3 \text { sodium nitrate }\end{array}$ & $\begin{array}{l}- \\
-\end{array}$ & $\begin{array}{l}12.15 \\
11.05 \\
12.01\end{array}$ & $\begin{array}{l}511.62 \\
457.86 \\
520.58\end{array}$ & $\begin{array}{l}42 \\
41 \\
43\end{array}$ \\
\hline
\end{tabular}

Control

\begin{tabular}{l|c|c|c|c}
\hline No nitrogen & 0 & 10.87 & 439.04 & 41 \\
\hline \hline $\begin{array}{l}\text { Least significant difference needed between } \\
\text { treatments: } \\
\text { 5-percent level }\end{array}$ & & 1.94 & 119.17 & 6.1 \\
\hline
\end{tabular}

\section{RATE OF BURNING OF CIGARS}

Table 4 presents the influence of the various nitrogen sources and other treatments on the relative rate of burning of cigars made from tobacco of the Caguas experiment.

The rate at which cigars burned when made from tobacco fertilized with 
ammonium sulfate was assigned a value of 100 , all other nitrogen-source influences on burning rate being compared to this value. Values below 100 are associated with a slower burning cigar tobacco and above 100 with faster burning tobacco. Values below 80 suggest very poor combustion.

Castor pomace and cottonseed meal, two natural organic nitrogen fertilizer sources, produced relative rates of burning higher than found for ammonium sulfate. Filter-press cake, an organic nitrogen source obtained as a byproduct from the sugarcane factories, had a burning rate of below 100 (table 4).

All nitrogen sources carrying calcium, such as calcium cyanamide, calcium ammonium nitrate, and calcium nitrate, produced tobacco that burned at rates of 100 or above. The only other inorganic source to have a relative burning rate above 100 was sodium nitrate.

The lowest burning rates were obtained from the cigars made from the urea- and sulfo-mag-fertilized tobacco, whereas the highest rate was obtained with tobacco fertilized with a mixture of $1 / 2$ urea plus $1 / 2$ cottonseed meal.

No fertilizer at all gave tobacco with a relative burning rate of 89 ; whereas, no-nitrogen-fertilized tobacco burned at almost the same rate as when ammonium sulfate was used-99 as compared to 100 .

Liming and minor-element mixtures did not increase the burning rate of the cigars (table 4 ).

\section{COLOR OF CIGAR ASH}

The color of the ash of the cigars made from tobacco fertilized with various nitrogen sources and other treatments are given in table 4. An arbitrary scale of colors was used in which 1 was pure-white cigar ash and 12 a black cigar ash.

Cigar smokers prefer a white ash; and it has been claimed that Puerto Rican cigar-filler tobacco tends to produce a dark ash. The regular nitrogen fertilizer for cigar tobacco in Puerto Rico is ammonium sulfate, and its color of cigar ash was rated 9.3 (table 4) which is a dark grey ash. Values less than 9.3 would be preferred as indicating a whiter cigar ash. Tobacco fertilized with calcium ammonium nitrate produced the whitest ash, 5.8. The color of this ash was a greyish-white, much lighter than the ammonium sulfate cigar ash, but still not the really creamy-white cigar ash that is preferred by discerning cigar smokers.

Urea and no fertilizer gave the next whitest cigar ashes. No other treatments used produced any significantly whiter ash when compared to the 9.3 of the cigars made from ammonium sulfate-fertilized tobacco. 
TABLE 4.-The influence of various fertilizer treatments on the relative rate of burning and color of the cigar ash, Caguas experiment, 1954

\begin{tabular}{l|c|c}
\hline \multicolumn{1}{c|}{ Fertilizer treatment } & $\begin{array}{c}\text { Relative rate of } \\
\text { burning }\end{array}$ & $\begin{array}{c}\text { Color of the cigar } \\
\text { ash }^{3}\end{array}$ \\
\hline No fertilizer & 89 & 6.5 \\
No nitrogen & 99 & 7.8 \\
Ammonium sulfate & 100 & 9.3 \\
Ammonium nitrate & 93 & 8.8 \\
Ammonium sulfate nitrate & 88 & 9.5 \\
Calcium ammonium nitrate & 105 & 5.8 \\
Calcium cyanamide & 106 & 7.5 \\
Calcium nitrate & 100 & 8.3 \\
Potassium nitrate & 92 & 9.0 \\
Sodium nitrate & 110 & 7.8 \\
Urea & 78 & 6.5 \\
Castor pomace & 114 & 9.5 \\
Cottonseed meal & 102 & 9.0 \\
Filter-press cake & 92 & 7.8 \\
1/2 ammonium sulfate plus 1/2 cottonseed meal & 112 & 9.5 \\
1/2 urea plus 1/2 cottonseed meal & 116 & 9.3 \\
1/3 urea plus 1/3 ammonium sulfate plus $1 / 3$ sodium & 97 & 8.5 \\
nitrate & & \\
Lime at 1 ton (CaCO ${ }_{3}$ ) per acre & 99 & 8.5 \\
Gypsum at 1 ton per acre & 93 & 10.3 \\
FTE at 100 pounds per acre & 90 & 10.0 \\
Sulfo-mag & 84 & 7.5 \\
\hline \hline
\end{tabular}

Least significant difference needed between treatments:

\begin{tabular}{l|l|l}
\hline 5-percent level & 25 & 2.1 \\
1-percent level & 34 & 2.7 \\
\hline
\end{tabular}

${ }^{1}$ All treatments received $100 \mathrm{lb}$. each of $\mathrm{N}$ and $\mathrm{P}_{2} \mathrm{O}_{6}$ and $150 \mathrm{lb}$. of $\mathrm{K}_{2} \mathrm{O}$ per acre, except where noted.

2 Rate of burning defined as the weight of cigar ash produced after 30 minutes of smoking. Ammonium sulfate treatment was rated as 100 in converting weights to relative values.

3 The arbitrary scale of colors was devised with 1 for pure white cigar ash and 12 for black ash.

4 Fritted trace elements, a relatively insoluble powdered glass containing $\mathrm{Mn}, \mathrm{Fe}$, $\mathrm{Zn}$, and Mo.

- A double sulfate of potash and magnesia containing not less than 21 percent of $\mathrm{K}_{2} \mathrm{O}$ and not less than 53 percent of magnesium sulfate.

\section{NICOTINE CONTENT}

The total nicotine contents of the tobaccos fertilized with various levels of $\mathrm{N}-\mathrm{P}_{2} \mathrm{O}_{5}-\mathrm{K}_{2} \mathrm{O}$ are given in table 5 .

The application of increasing amounts of nitrogen fertilizer increased the 
total nicotine content of the tobacco from 0.72 to 0.96 percent with none to 100 pounds of nitrogen per acre. For unknown reasons the use of 150

TABLE 5.-The influence of fertilizer treatments on the total nicotine percentage and the percentage of total nicotine in free form of cigar-filler tobacco, first crop, Aibonito experiment, 1951-52

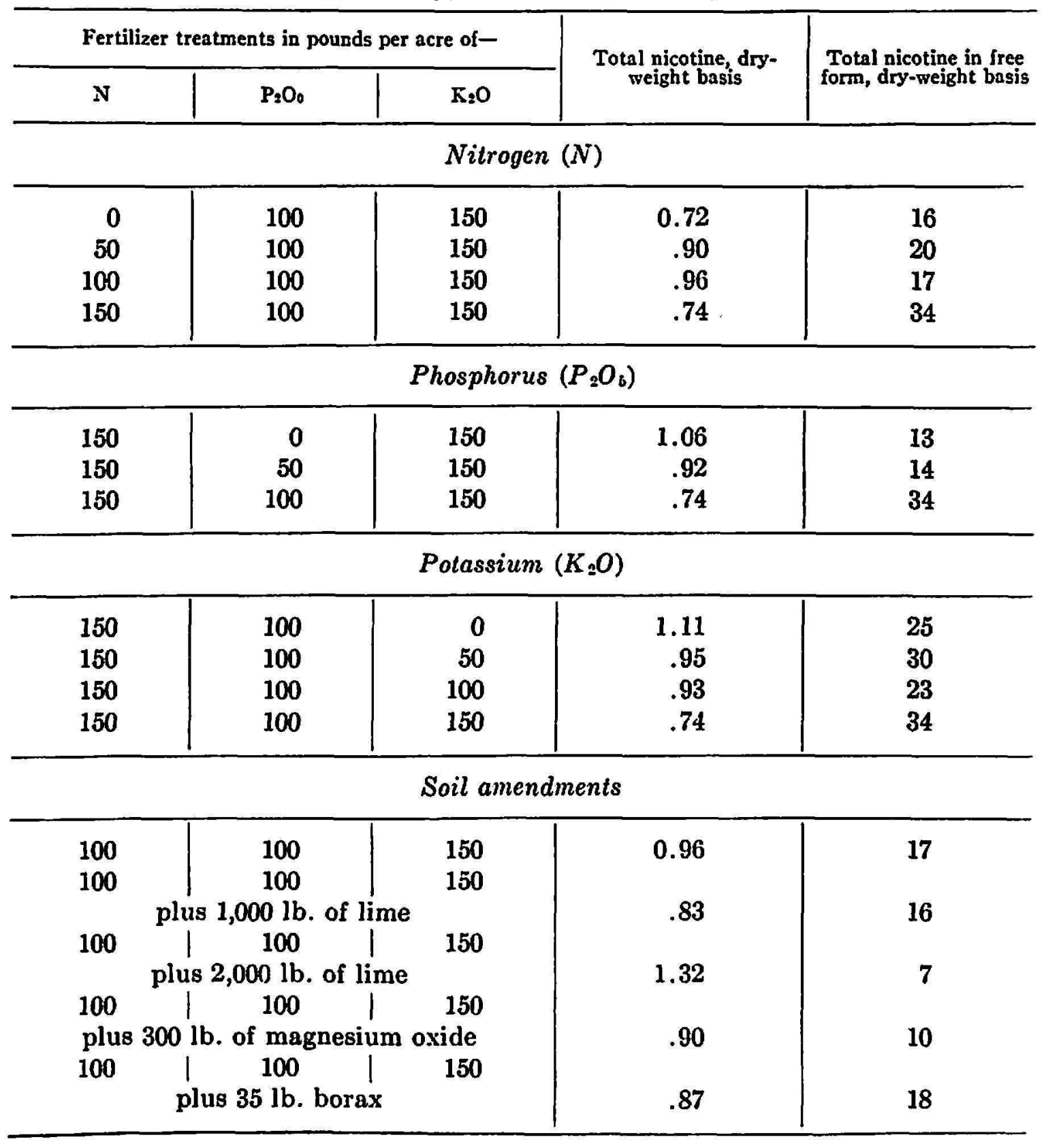

pounds of nitrogen per acre decreased this to 0.74 percent. The nicotine in free form tended to increase with increasing nitrogen application, including the 150-pound nitrogen rate (table 5). Increases in nicotine are normally associated with increased nitrogen applications (4).

The omission of a phosphate fertilizer caused an increase in the nicotine 
content of the tobacco. The nicotine content decreased as phosphates were applied. No phosphates produced tobacco with a total nicotine content of 1.06 percent as compared to 0.74 percent when 100 pounds of $\mathrm{P}_{2} \mathrm{O}_{5}$ per acre was applied.

The use of increasing amounts of potash fertilizers tended to lower the total nicotine content of the leaf. Highest nicotine values for all treatments were found associated with the no-potash treatment and values decreased with increasing potash applications (table 5). Free-nicotine values were not consistently correlated with the size of potash applications.

The use of 2,000 pounds of lime per acre produced the highest total nicotine content of the entire experiment, 1.32 percent (table 5). Yet, the use of 1,000 pounds of limestone gave no increases in nicotine as compared to the no-lime treatment. The free nicotine, however, was lowest with 2,000 pounds of lime per acre, and increased with the 1,000 pounds of lime per acre.

Neither magnesium oxide nor boron as borax produced any appreciable change in the nicotine content of the tobacco when applied to the soil.

\section{DISCUSSION}

Let us return again to the questions concerning the influence of fertilizers on cigar-filler tobacco quality in light of the results from our experiments. Does too much fertilizer give good yields, but produce poorer grades of tobacco? The results indicate that higher yields do not lower tobacco quality. In fact, for nitrogen, increasing yields accompanied increasing quality as measured by the price paid per pound of tobacco. It should be remembered that tobacco is grown only for its leaf. Any nutrient deficiency severe enough to prevent good growth will usually produce leaves which are of inferior quality as to size, color, and thickness $(3,6)$.

Can certain fertilizer elements increase the quality of the tobacco when used at rates in excess of that needed for optimum yields of tobacco? The answer to this appears to be no, in light of the results obtained from the experiments performed. Nitrogen, phosphates, and potash fertilizers did not produce higher quality tobacco when used at rates greater than needed for significant yield increases. This fact is shown graphically in figure 1. But nitrogen both increased yield and the price-per-pound value of the tobacco. More than $\mathbf{5 0}$ pounds of nitrogen per acre failed to increase either yield or price per pound.

Phosphates increased yield but did not produce any marked increase in the price per pound of tobacco. Potash failed to increase yield or the quality of the tobacco, at least as evaluated by the price per pound. This finding seems at odds with the popular concept of the farmers that potash is needed for quality even when not for yields. Bowling and Brown 


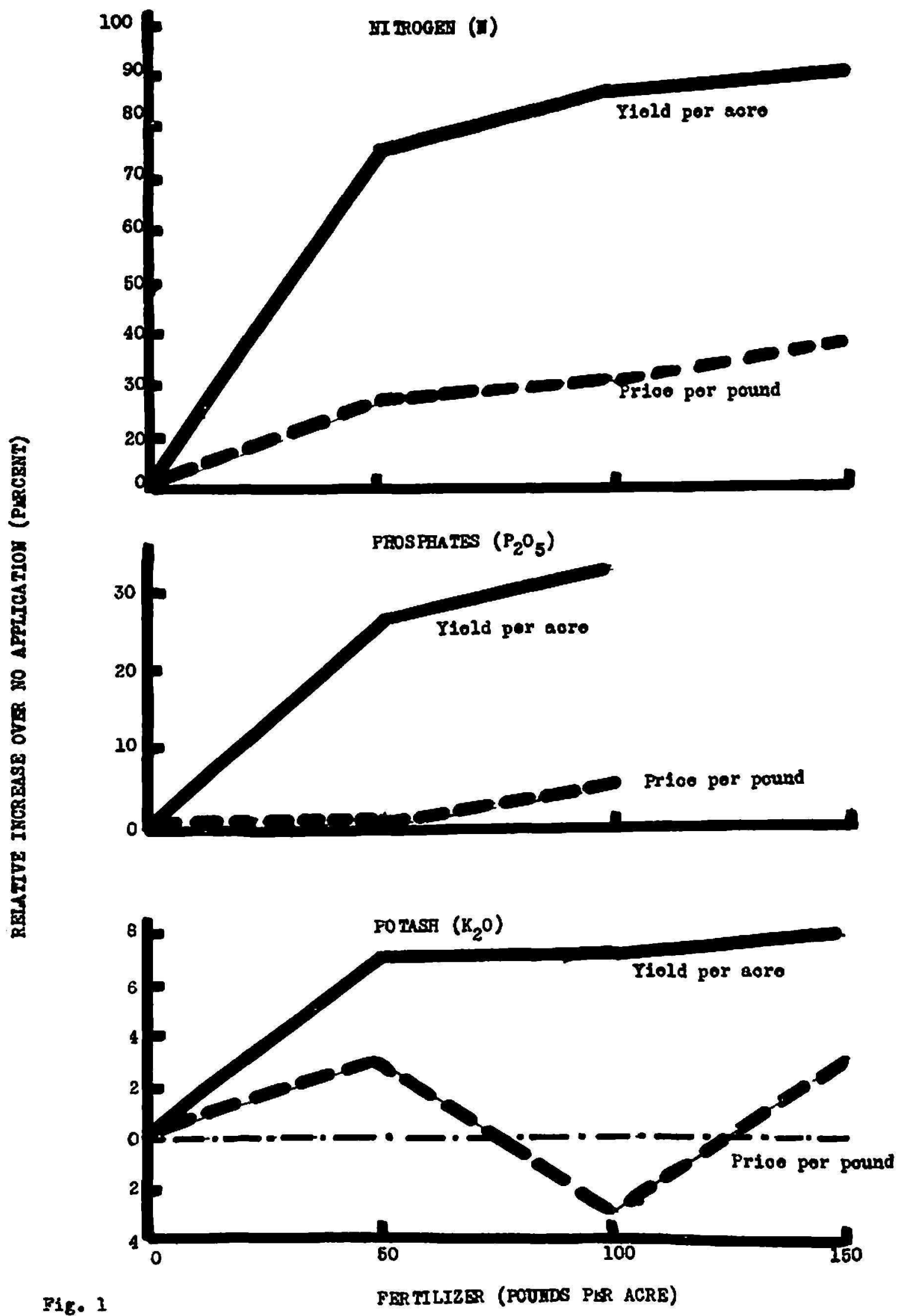

Fig. 1.-Influence of fertilizers $\left(\mathrm{N}-\mathrm{P}_{2} \mathrm{O}_{5}-\mathrm{K}_{2} \mathrm{O}\right)$ on relative increases in yield per acre and price per pound of cigar-filler tobacco in Puerto Rico. 
(2) obtained significant increases in price per pound of Maryland tobacco when the yield per acre did not increase significantly. Yet, it appears that sufficient potash was present in the Juncos clay to provide all that was necessary for maximum crop yield and quality.

The use of lime and magnesium oxide produced increases in yields short of significance, but quality, as judged by price per pound of tobacco, did increase significantly. So that the responses in yield and quality of tobacco to soil amendments were not the same as to the major fertilizer elements.

The relationship between yield and quality of tobacco, as influenced by the fertilizers used in the experiments analyzed herein, cannot be regarded as applicable to all commercial tobacco-growing in Puerto Rico until further work is done using other tobacco soils.

\section{SUMMARY}

The influence of fertilizers on cigar-filler tobacco quality, as judged by price per pound, was investigated, using three crops of a major-element fertilizer $\left(\mathrm{N}-\mathrm{P}_{2} \mathrm{O}_{5}-\mathrm{K}_{2} \mathrm{O}\right)$ experiment at Aibonito on a Juncos clay and a source-of-nitrogen experiment at Caguas clay. The results obtained were as follows:

1. The use of 50 pounds per acre of nitrogen increased the quality of the tobacco significantly when compared to the no-nitrogen treatment.

2. Rates up to $\mathbf{1 5 0}$ pounds per acre of nitrogen did not increase significantly either yield or quality of tobacco per acre over the 50-pound-per-acre nitrogen treatment. However, the quality of the tobacco was not reduced by the high nitrogen applications.

3. Phosphates and potash failed to increase the quality of the tobacco.

4. Lime and magnesium oxide increased the quality of the tobacco.

5. The other sources of nitrogen used failed to increase the quality of the tobacco, as far as price per pound was concerned, beyond the price of the tobacco produced with ammonium sulfate.

6. The burning rates of cigars made with tobacco fertilized with various nitrogen sources showed urea to give the slowest rate of burning, and a mixture of urea and cottonseed meal the most rapid. Ammonium sulfate as a nitrogen source was about intermediate between these.

7. The nicotine content of the tobacco increased with applications of nitrogen up to the 100-pound-per-acre level. Phosphate and potash applications tended to lower the nicotine content of the tobacco leaf.

8. A discussion of the influence of fertilizers on quality of the tobacco is presented to aid the farmer in his use of fertilizer to increase tobacco quality. Warning is also given that these relationships on the relation between yield and quality of tobacco cannot be regarded as applicable to all commercial 
tobacco-growing in Puerto Rico until further work is done on other tobacco soils.

\section{RESUMEN}

Se investigó el efecto de los abonos sobre la calidad del tabaco en rama para tripa. Se usaron los datos de tres cosechas de un experimento que se sembró en Aibonito en suelo Juncos arcilloso, abonado con elementos fertilizantes mayores $\left(\mathrm{N}-\mathrm{P}_{2} \mathrm{O}_{5}-\mathrm{K}_{2} \mathrm{O}\right)$ y de otro sembrado en Caguas en suelo Caguas arcilloso, abonado éste con distintos fertilizantes nitrogenados.

Los resultados fueron los siguientes:

1. El uso de 50 libras por acre de nitrógeno aumentó significativamente la calidad del tabaco cuando este tratamiento se comparó con el que no llevaba nitrógeno.

2. Las aplicaciones de nitrógeno, hasta 150 libras por acre, no aumentaron significativamente los rendimientos ni la calidad del tabaco sobre los del tratamiento con 50 libras de nitrógeno por acre. Sin embargo, la calidad del tabaco no se redujo con las mayores cantidades de nitrógeno aplicado.

3. Ni los fosfatos ni la potasa aumentaron la calidad del tabaco.

4. La cal y el magnesio aumentaron la calidad del tabaco.

5. Las distintas fuentes de nitrógeno usadas no aumentaron la calidad del tabaco lo suficiente para influir sobre el precio del producto sobre el que se logró con las aplicaciones de sulfato amónico.

6. La capacidad de quema del tabaco abonado con distintos abonos nitrogenados demostró que el tratado con urea tardó más en quemar y que el abonado con una mezcla de urea y pulpa de semilla de algodón fué el que más rápidamente quemaba. La capacidad de quema del tabaco abonado con sulfato amónico quedó en término medio entre los tabacos abonados con urea y con la mezcla de urea y pulpa de semilla de algódon.

7. El contenido de nicotina aumentó con las aplicaciones de 100 libras de nitrógeno por acre. Hubo la tendencia de las aplicaciones de fosfatos y potasa a bajar el contenido de nicotina en la hoja de tabaco.

8. Se discute el efecto de los fertilizantes sobre la calidad del tabaco y el uso que el agricultor puede darle a esta información para mejorar la calidad de su producto.

\section{LITERATURE CITED}

1. Anonymous, Free nicotine in tobacco, Official and Tentative Methods of Analyses of Assn. of Off. Agr. Chemists, pp. 135-6, 1945.

2. Bowling, J. D., and Brown, D. E., Role of Potash in Growth and Nutrition of Maryland Tobacco, USDA Tech. Bul. 933, April 1947.

3. Cibes, H. and Samuels, G., Mineral-Deficiency Symptoms Displayed by Tobacco Grown in the Greenhouse under Controlled Conditions, Agr. Exp. Sta. Univ. P. R., Río Piedras, P. R., Tech. Paper 23, 1957. 
4. Garner, W. W., Bacon, W. W., Bowling, J. D., and Brown, D. E., The Nitrogen Nutrition of Tobacco, USDA, Tech. Bul. 414, April 1934.

5. Landrau, P. Jr., Samuels, G., Alers-Alers, S., and González-Molina, C., The influence of fertilizers on tobacco yields, J. Agr. Univ. P. R. 43 (1) 56-68, 1959.

6. McMurtrey, J. E., Jr., Symptoms on Field-Grown Tobacco Characteristic of the Deficient Supply of each of Several Essential Chemical Elements, USDA Tech. Bul. 612, April 1938. 